\title{
Brazilian Plecoptera 4. Nymphs of perlid genera from south- eastern Brazil
}

\author{
C.G. Froehlich 1
}

Nymphs ot the three perlid genera known from southeastern Brazil, Anacroneuria, Kempnyia and Macrogynoplax, are distinguished morphogically and a key is provided for their determination.

Plécoptères brésiliens 4. Les larves des genres de Perlidae du Sud-Est du Brésil.

L'auteur précise les caractères morphologiques propres à chacun des trois genres de Perlidae du Sud-Est du Brésil. Anacroneuria, Kempnyia et Macrogynoplax, et il propose une clef de détermination de ces larves.

In southeastern Brazil three well-defined genera of the subfamily Acroneurinae (the only Neotropical Perlidae) occur, viz., Anacroneuria Klap., Kempnyia Klap. and Macrogynoplax End. The only nymphs to have been described and figured are those of Anacroneuria (Needham \& Broughton 1927. and especially Hynes 1948 ; figures of head, mandi. ble and maxilla are given in Illies 1964), although those of Macrogynoplax have been briefly characterized by Froehlich (1984). In the present paper a comparative discussion of some nymphal characters is presented, based on a study of late instar nymphs of three species of Anacroneuria, five species of Kempnyia (of which only $K$. gracilenta (End.) has been determined to species), and one species of Macrogynoplax ( $M$. veneranda Froehlich). All nymphs come from stony streams of the coastal range of the State of Sảo Paulo.

The general shape of the body is perlid-like and similar in the three genera (for Anacroneuria see Hynes, l.c., Fig. 1 A). The body is clothed with dark hairs but the clothing hairs of the head may be thinner and lighter in colour in some species of Anacroneuria and Kempnyia, and in Macrogynoplax. Ana-

1. Departamento de Biologia, FFCLRP, Universidade de Sāo Paulo, 14100 Ribeirào Preto, SP, Brasil. croneuria (Fig. 1) and Macrogynoplax possess two ocelli; in the latter genus they are nearer to each other in the nymphs than in adults (Fig. 3). Kempnyia has three ocelli, the median one being smaller than the others (Fig. 2); probably in some species, as in the adults, the median ocellus may sometimes be minute or absent. There is no occipital ridge.

The mouth parts are, on the whole, rather uniform. Macrogynoplax differs from the other two genera by the long. thin maxillary and labial palpi (Figs. 6 and 7), and by the more protruding basal teeth, and by the wide angle between the mesial brush and the ventral row of bristles of the mandibles (Fig. 5). For comparison, a mandible, a maxilla and the labium of a Kempnyia are shown in Figs. 8.10.

The front legs, which are unmodified in Anacroneuria and Kempnyia, form in Macrogynoplax a pair of raptorial structures (Fig. 4). The femora are thickened and bear anteriorly a receiving groove for the tibiae. The groove is clothed with thickly set short hairs and is garded in the basal half by two rows of bristles. The tibiae are curved towards the femora, and clothed with thickly set short hairs on the side that fits into the femoral groove. The posterior fringe of long hairs is moderately dense on the femora, thinner and with shorter hairs on the tibiae. 

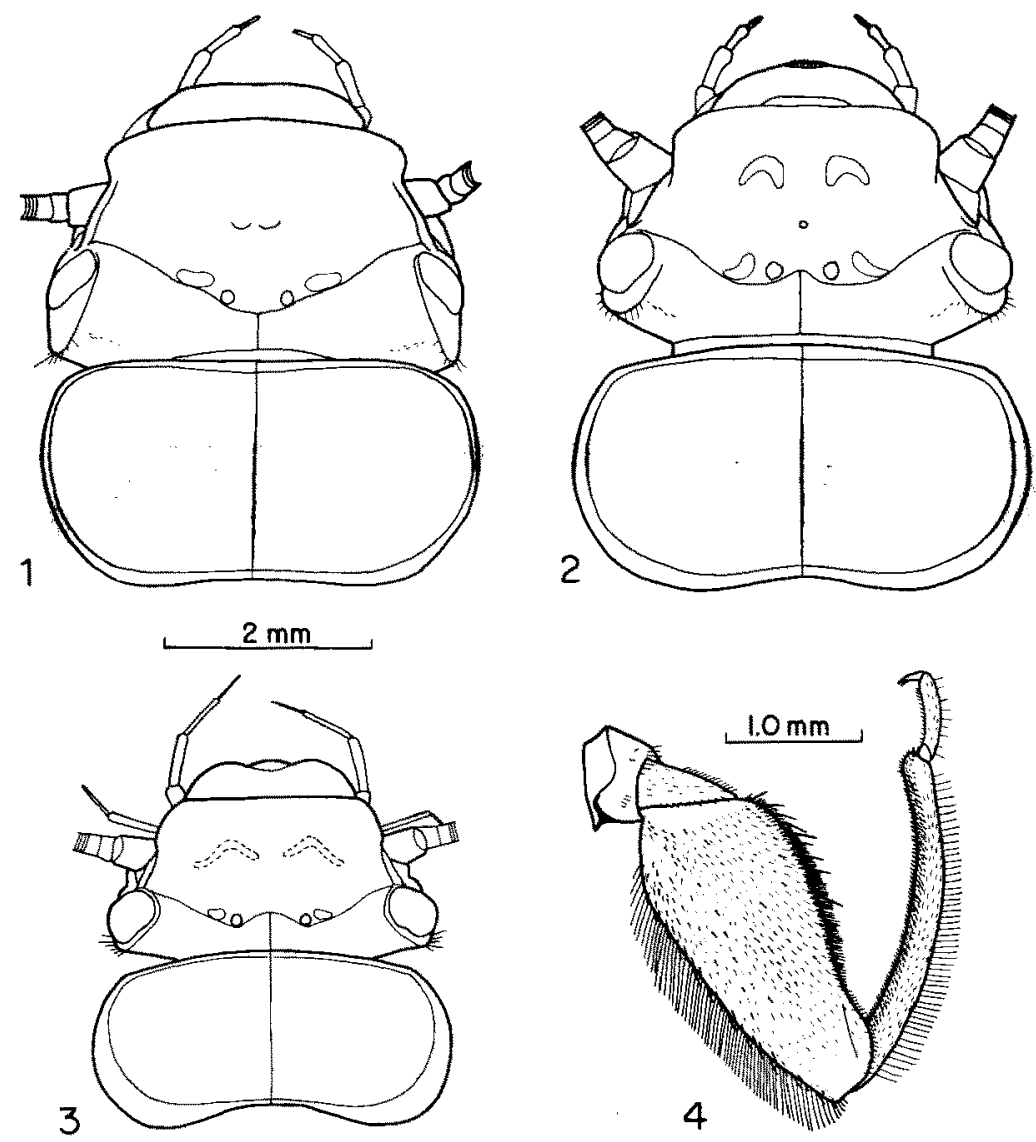

Fig. 1.3. Outhnes of head and prothorax : 1, Anacronetria sp. ; 2, Kempnyia sp. : 3, Macrogynoplax veneranda. Fig. 4. Macrogynoplax veneranda, fore leg, dorsal view. 
(3)
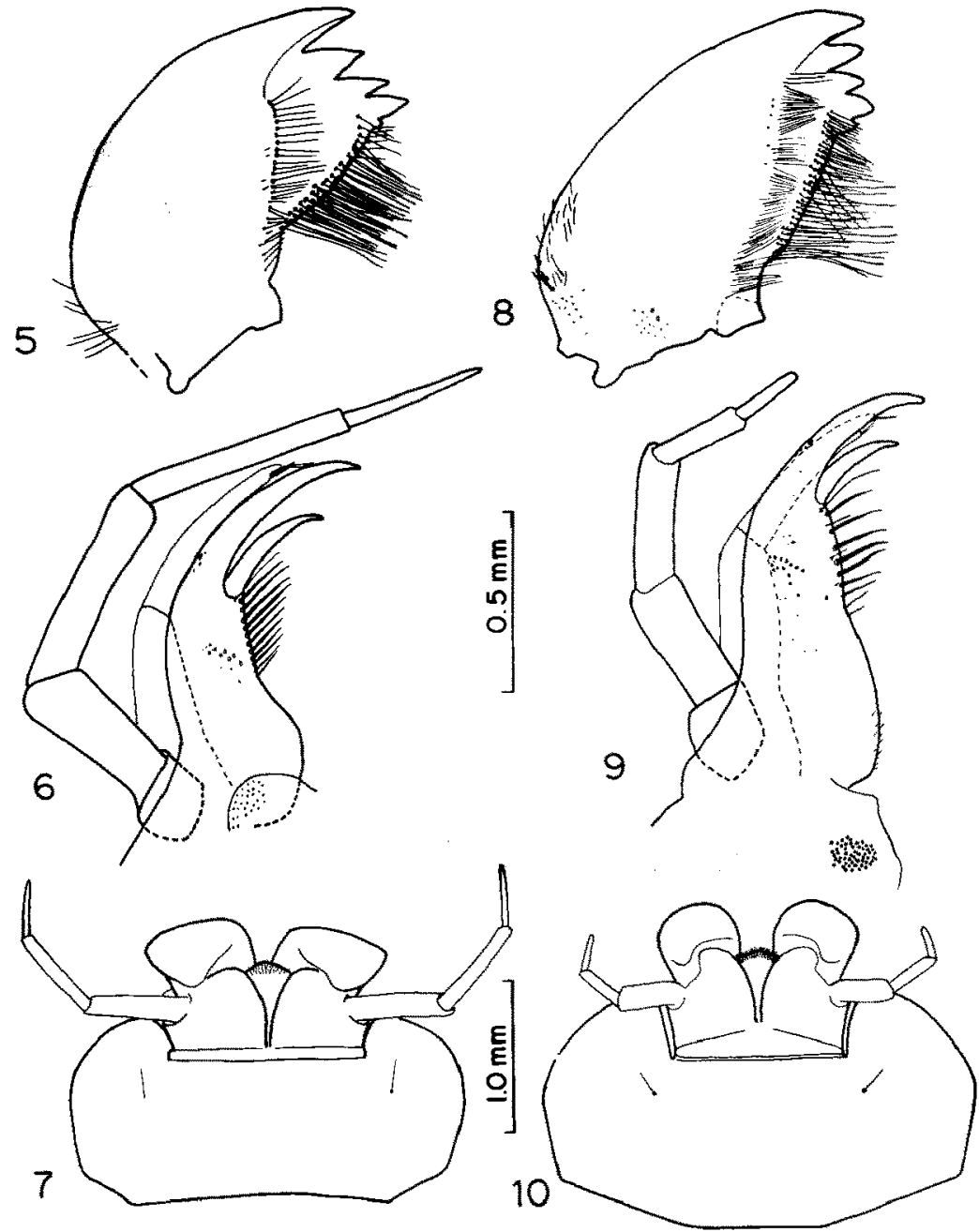

Fig. 5.7. Macrogynoplax veneranda, mouth parts, ventral view; 5 , right mandible; 6 , lacinia, galea and palpus of right maxilla ; 7 . labium. Fig. 810 . Kempnyia sp., mouth parts, vent ral view ; 8 , right mandible : 9. lacinia, galea and palpus of right maxilla; 10, labium. 
Kempnyia (Fig. 11) and Macrogynoplax have, on each side, two tufts of supra-coxal gills on the proas well as on the mesothorax (gills $\mathrm{C}_{1}$ and $\mathrm{C}_{2}$ of Hynes 1941), and one pair of pleural (substigmal) gills, each gill with three main branches, between the pro- and the mesothorax, and between the mesoand the metathorax (gills I and II of Hynes). Above and posterior to the metathoracic legs there are three gill tufts, of which two are probably gills $C_{3}$, and the third, a displaced, single-branched gill III. A pair of anal gills is present, except in onc species of Kempnyia. The three species of Anacroneuria have gills as described by Hynes 1948. Gills I, II and III have three main branches each, while gill $\mathrm{C}_{1}$ is represented by two tufts (Fig. 12). Gills $C_{2}$ and $C_{3}$, and the anal gills are absent.

A practical key for the determination of late instar nymphs of the three genera follows:

1 - Front legs raptorial ..... Macrogynoplax Front legs not modified ............ 2
2 - Thoracic gills $\mathbf{C}_{1}, C_{2}$ and $C_{3}$ present. Usually with three ocelli and anal gills ................ Kempnyia

- Thoracic gills $C_{2}$ and $C_{3}$, and anal gills absent. Two ocelli.....

Anacroneuria

\section{Literature cited}

Froehlich (C.G.). 1984. - Brazilian Plecoptera 3. Macrogynoplax veneranda sp. n. (Perlidae Acroneuriinae). Annls Limnol. 20 : 39.42

Hunes (H.B.N.). 1941. - The taxonomy and ecology of the nymphs of British Plecoptera with notes on the adults and eggs. Trans. R. ent. Soc. Lond., 91 : 459.557.

Hynes (H.B.N.). 1948. - The nymph of Anacroneurio aroucana Kimmins (Plecoptera, Perlidac). Proc. R. ent. Soc. Lond., (A) 23 $(10-12)=105.110$

Illies (J.). 1964 - Südamerikanische Perlidae (Plecople ra), besonders aus Chile und Argentinien. Beirr. Neorrop. Fauna, 3 (3): 207-233.

Needham (J.G.) \& Broughton (E.). 1927. - Central American sto neflies with descriptions of new species (Plecoptera). $J$. New York ent. Soc, 35: 109-121. 
(5)
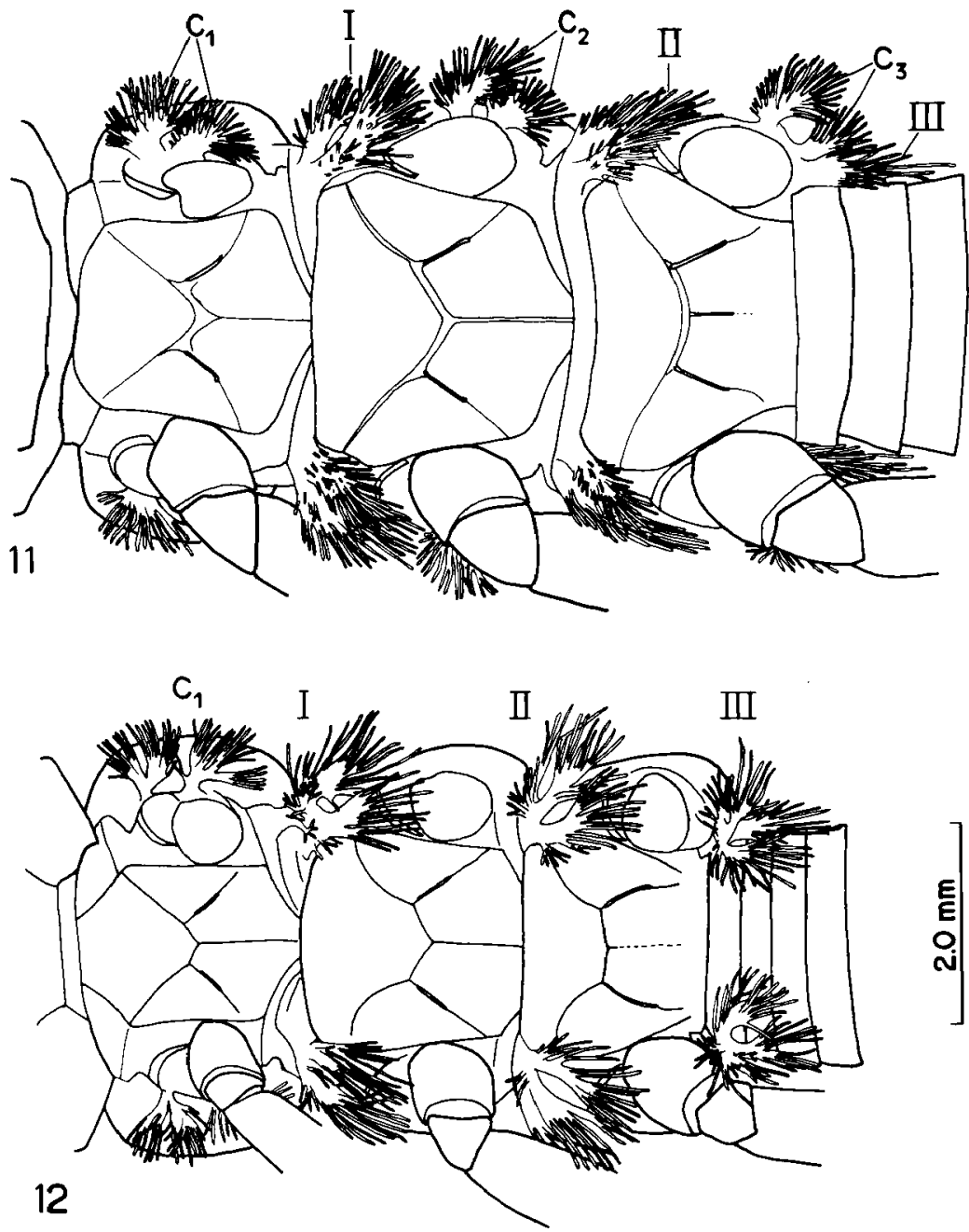

$\left.\begin{array}{c}\text { E } \\ \text { E } \\ \mathbf{N}\end{array}\right]$

Fig. 11-12. Ventral view of thorax showing the gills, legs removed from the left side; 11, Kempnyia sp. ; 12, Anacroneuria sp. 